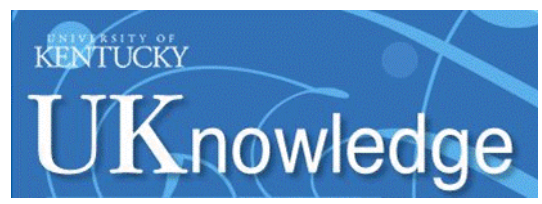

Kentucky Journal of Equine, Agriculture, \& Natural Resources Law

\title{
Local Sustainability Movement Rides Wave of Evolving Federalism to 'Axe' Private Property Rights
}

Lawrence A. Kogan

Institute for Trade, Standards and Sustainable Development

Follow this and additional works at: https://uknowledge.uky.edu/kjeanrl

Part of the Property Law and Real Estate Commons

Right click to open a feedback form in a new tab to let us know how this document benefits you.

\section{Recommended Citation}

Kogan, Lawrence A. (2015) "Local Sustainability Movement Rides Wave of Evolving Federalism to 'Axe' Private Property Rights," Kentucky Journal of Equine, Agriculture, \& Natural Resources Law. Vol. 7: Iss. 3, Article 4.

Available at: https://uknowledge.uky.edu/kjeanrl/vol7/iss3/4

This Article is brought to you for free and open access by the Law Journals at UKnowledge. It has been accepted for inclusion in Kentucky Journal of Equine, Agriculture, \& Natural Resources Law by an authorized editor of UKnowledge. For more information, please contact UKnowledge@lsv.uky.edu. 


\title{
LOCAL SUSTAINABILITY MOVEMENT RIDES WAVE OF EVOLVING FEDERALISM TO ‘AXE' PRIVATE PROPERTY RIGHTS ${ }^{1}$
}

\author{
Lawrence A. Kogan, Esq.*
}

\section{INTERNATIONAL SUSTAINABLE DEVELOPMENT AND POST- MODERNISM}

he concept of sustainable development ("SD"), originally
articulated in 1987 by the United Nations ("UN") World Commission on Environment and Development, ${ }^{2}$ has long been recognized as being simultaneously global and local in political scope and ambition. It embodies an ostensibly universally applicable (and, until recently, legally unenforceable) set of twenty-seven intergenerational principles integrating environmental, economic, and social concerns enumerated in the 1992 UN Rio Declaration on Environment and Development. ${ }^{3}$ This includes the scientifically progressive yet economically harmful Principle 15 , known as the "precautionary principle." Additionally, it incorporates a comprehensive road map for national and subnational governmental implementation of those principles, known as Agenda $21 .^{4}$

- Lawrence A. Kogan is chief executive of the nonprofit Institute for Trade, Standards and Sustainable Development (ITSSD) and managing principal of The Kogan Law Group, P.C.

${ }^{1}$ This article is based largely on the author's presentation from the Eighteenth Annual National Conference on Private Property Rights of the Property Rights Foundation of America. See Lawrence A. Kogan, Institute for Trade, Standards and Sustainable Development, U.S. State \& Local Implementation of International Sustainable Development: An Expression of the 'New' Post-Modern Federalism, National Conference on Private Property Rights (Oct. 25, 2014) (annotated outline available https://nebula.wsimg.com/f50d3508fe164240603e13c622c99558?AccessKeyId=39A2DC689E4CA87C 906D\&disposition $=0$ \&alloworigin $=1^{\prime}$ ).

${ }^{2}$ See Rep. of the World Comm'n on Env't \& Dev.: Our Common Future, U.N. Doc. A/42/427, Annex I (1987).

${ }^{3}$ U.N. Conference on Env't \& Dev., Rio de Janeiro Braz., June 3-14, 1992, Rio Declaration on Environment and Development, available http://www.unep.org/Documents.Multilingual/Default.asp?documentid=78\&articleid=1163.

${ }^{4}$ U.N. DEP'T OF ECON. \& SOC. AFFairs, Div. FOR SUSTAINABLE DEV., SuSTAINABLE DEVELOPMENT IN THE 21ST CENTURY (SD21): REVIEW OF IMPLEMENTATION OF AGENDA 21 AND THE RIO PRINCIPLES Jan. 2012), available at http://www.uncsd2012.org/content/documents/194Synthesis\%20Agenda\%2021\%20and\%20Rio\%20pri nciples.pdf. 
Chapter 28 of Agenda 21 ("local Agenda 21" or "LA21") specifically encourages the establishment of mechanisms to promote cooperation and coordination between local authorities internationally. ${ }^{5}$ It has effectively provided state and local authorities with an environmental advocacy platform at the international level. ${ }^{6}$ Since the conclusion of the 2002 UN Johannesburg World Summit on Sustainable Development and the 2007 signing of the European Union Lisbon Treaty, the SD concept has been reformulated as a legally operable and enforceable norm that obliges national and regional governments " . . to promote long-term economic prosperity and social justice within the limits of ecological sustainability."

Those unfamiliar with SD may not realize that it is rooted in an uneasy late twentieth century political and philosophical compromise between Marxism and capitalism, ${ }^{8}$ which some commentators have spiritedly debated and referred to as the "Third Way." "The Third Way movement was developed by the centre-left in the US [during the Clinton administration], and then the UK [the Blair administration], as a response

${ }^{5}$ See Leslie Hom, The Making of Local Agenda 21: An Interview with Jeb Brugmann, 7 LOCAL ENV'T 3, 251, 252 (2002).

${ }^{6} \mathrm{Id}$.

${ }^{7}$ Frances Aldson, EU Law and Sustainability in Focus: Will the Liberty Treaty Lead to 'The Sustainable Development of Europe'?, 23 Envtl. Law \& Mgmt. 5, 284 (2011) (citing KLAUS BOSSELMANN, THE PRINCIPLES OF SUSTAINABILITY: TRANSFORMING LAW AND GOVERNANCE $53(2008))$.

${ }^{8}$ See generally George Liodakis, Material, Social and Theoretical Aspects of Sustainable Development at the World Economics Association Sustainability Conference 7-10 (Sept. 24-Oct. 21, 2012) (noting how "Marx's fruitful insight led him to depict the relation between nature and society as a metabolic relation increasingly disrupted by the development of capitalism, both in agriculture and industry ... This insight has served as the basis for a considerable recent literature concerning this growing metabolic rift and its implications for a sustainable and ecologically compatible development ... As argued throughout this paper, however, due to the essential features of capitalism, it is impossible to have reforms of capitalism adequate to the task of creating conditions of social and ecological sustainability, not to speak of a truly sustainable human development.").

9 Compare ANTHONY GIDDENS, THE THIRD WAY: THE RENEWAL Of SOCIAL DEMOCRACY (1998) with The Third Way Revealed, ECONOMIST (Sept. 17, 1998), http://www.economist.com/node/165553 (vehemently criticizing Anthony Giddens' book). See also Anne Bartlett, Greening London: Sustainability, Politics and the Third Way, Chap. 14 in Human Settlement Development - Vol. IV, Encyclopedia of Life Support Systems (United Nations Educational Scientific and Cultural Organization (UNESCO 2003), available at: http://www.eolss.net/samplechapters/c14/E1-18-09-03.pdf ("[F]or many of the [...] architects of the Third Way, sustainability [...] demands a more flexible and in some respects syncretic approach, often bringing togegher apparently incongruous themes or groups all in the name of political compromise. Sustainability...requires an accommodation between the traditionally opposed factions of capitalism and environmentalism in an attempt to achieve a modus vivendi in which all sets of actors can pursue their agendas. It requires a 'meeting of minds' - a reinvigoration of the sustainability agenda - in which business, environmental requisites and consumer demand can be harnessed in a mutually beneficial relationship."). Id., at p. 4 . 
to new challenges. ${ }^{10}$ It is, effectively, an update of the New Dea ${ }^{11}$ and the "social market economy"12 of the European continental welfare state, ${ }^{13}$ and "closely related to 'new Keynesian' economics" which views 'market failures' "as arising from the existence of externalities, the 'public good' nature of some goods and monopoly..."14

${ }^{10}$ See James Sloam, 'Blair, the Third Way and European Social Democracy: A New Political Consensus?, Paper Presented to "Britain After Blair" Conference (Chicago, IL, 29 August 2007), available at p. 2, at: http://www.rose-hulman.edu/ casey1/BAB-Sloam.pdf (describing how "Labour's Third Way has provided a coherent political philosophy that has been enacted in government. Its central aims of have been to promote the primacy of the economy, and to concentrate spending priorities on social investment within the context of an active welfare state" (emphasis in original)). Id.

${ }^{11}$ See Margaret Weir, The Collapse of Bill Clinton's Third Way, in Producing Public Sociology: Contributions of Berkeley Faculty (2000), available at: http://publicsociology.berkeley.edu/publications/producing/weir.pdf;

http://publicsociology.berkeley.edu/publications/producing/contents.php ("This transformative strategy had three components: 1) To counter distrust of the federal government, policy would work through market mechanisms or the states and it would "reinvent" government; 2.) To counter racially-charged "wedge" issues, such as crime and welfare, policy would set clear expectations for individual responsibility and impose sanctions on bad behavior. It would, however, provide resources to assist people if they lived up to their part of this bargain. The President encapsulated this bargain in the aphorism, 'If you work, you shouldn't be poor.' 3.) To counter arguments that social spending was too expensive, policy would highlight the long-term benefits of "investing" in people so that they could be productive workers and citizens. This approach to policy can be distinguished from two Democratic alternatives. It most visibly departed from "old Democratic" policy orientations in its forthright embrace of responsibility and expectations for individual behavior as conditions for beneficiaries. But it also envisioned a different relationship between government and the market than traditional New Deal policies.") Id., at pp. 2-3.

${ }^{12}$ See Christian Joerges and Florian Rodl, "Social Market Economy" as Europe's Social Model?, European University Institute Working Paper LAW No. 2004/8 (2004), available at: http://cadmus.eui.eu/bitstream/handle/1814/2823/law04-8.pdf (describing how the term "social market economy" "was invented by the German Professor of economics, Alfred Muller-Armack in 1946. In an article, he presented the 'social market economy' as a third way between 'laissez-faire liberalism' and 'planned economy' with the inherent threat of socialization.") Id., at p. 12. See also Jurgen Jeske, The 'Third Way' Between State Intervention and the Free Market, Taipei Times (March 3, 2015), available at: http://www.taipeitimes.com/News/editorials/archives/2015/03/03/2003612636.

${ }^{13}$ See Jochen Clasen and Daniel Clegg, Does the Third Way Work? The Left and Labour Market Policy Reform in Britain, France, and Germany, in Jane Lewis and Rebecca Surender, Welfare State Change: Towards a Third Way? (Oxford Univ. Press 2005), available at: http://www.socialwork.ed.ac.uk/_data/assets/pdf_file/0012/9021/ClasenCleggir.pdf;

http://www.oxfordscholarship.com/view/10.1093/0199266727.001.0001/acprof-9780199266722-

chapter-5 ("The Third Way referred originally to the self-conscious 'rebranding' of the centre-left, as advocated by Tony Blair and some of his close advisers in Britain [...] However, in more scholarly debates about welfare states and their reform, the term is also increasingly employed as shorthand for the policy mix perceived to be best suited to reconciling economic performance and social justice in a transformed international economy. ") Id., at p. 89.

${ }^{14}$ See Philip Arestis, "New Consensus," New Keynesianism, and the Economics of the "Third Way," Levy Economics Institute of Bard College, Working Paper No. 364 (2002), at p. 1, available at: $\mathrm{http} / /$ www.levyinstitute.org/publications/new-consensus-new-keynesianism-and-the-economics-ofthe-third-way; http://www.levyinstitute.org/pubs/wp_364.pdf ("We argue that the ideas of the "third way" are closely related with "new Keynesian" economics...") Id. 
Indeed, SD has been explicitly hailed as a "progressive alternative to neoliberalism in the twenty-first century." ${ }^{15}$ The subsequent compromise embodied the post-modernist European movement's key precepts that had evolved since WWII: a rejection of the Enlightenment-era science, economics, law, and political philosophies upon which America was founded. ${ }^{16}$

The precautionary principle's philosophical underpinnings, for example, are closely related to post-modernism. The precautionary principle focuses on the uncertainties and potential hazards that new technologies and industries may pose to human health and the environment instead of focusing on the risks that specific uses and exposures actually cause. It also shifts the legal burden of proof from the government showing harm to economic actors showing safety, and reduces the scientific and legal threshold needed to establish harm for regulatory purposes from causation to correlation. Consequently, the precautionary principle directly challenges the conventional modern scientific paradigm that requires strong causal evidence, ${ }^{17}$ thereby enabling more frequent, disproportionate, and greater federal agency regulation of economic and technological activities at the expense of individualism and private property rights. Finally, the precautionary principle has prompted foreign governments to suspend intellectual property right protections over U.S. innovations to foster broader dissemination of environmental technologies to SD. ${ }^{18}$

${ }^{15}$ See Lena Sommestad, Economics of Sustainable Development - A Progressive Alternative to Neoliberalism in the Twenty-First Century, in MARKET AND STATE IN EUROPEAN SOCLAL

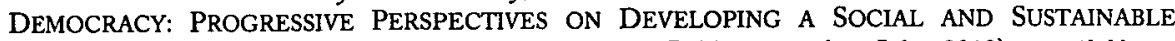
MARKET MODEL 16 (Anke Hassel \& Christoph Pohlmann eds., July 2010), available at http://library.fes.de/pdf-files/id/ipa/07338.pdf.

${ }_{16}$ See Lawrence A. Kogan, Science for the Picking, HEARTLAND INST., SOMEWHAT REASONABLE BLOG (July 27, 2014), http://blog.heartland.org/2014/07/science-for-the-picking/.

${ }^{17}$ See Lucas Bergkamp. \&Lawrence Kogan, Trade, the Precautionary Principle and Post-Modern Regulatory Process: Regulatory Convergence in the Transatlantic Trade and Investment Partnership, EUR. J. RISK REG. 493, 499 (2013).

${ }^{18}$ See Lawrence A. Kogan, Global Efforts to 'Rebalance' Private and Public Interests in Intellectual Property: Chaos IS the New Normal, Panel at the Annual Meeting of the Intellectual Property Law Section of the New York State Bar Association: International Changes in IP: Is it Chaos or the New Normal? (Jan. 28, 2014) (discussing how "governments around the world have more flexibility and have readily chosen to exercise the option of employing 'public interest' grounds beyond the strictures of government product authorization, market access and/or procurement regulations, as the preferred basis for monitoring, overseeing and ultimately governing exclusively private party contractual relations. For example, even where private parties have not otherwise committed an illegal act, governments have 


\section{U.S. GOVERNMENT-BACKED INTERNATIONAL SUSTAINABLE DEVELOPMENT INITIATIVES}

The United States first officially embraced and promoted SD at the national and international levels through the Clinton Administration's President's Council on Sustainable Development ${ }^{19}$ and related Task Forces ${ }^{20}$ and Reports, ${ }^{21}$ and National Security Strategy, which had called for promotion of SD abroad. ${ }^{22}$ The Obama administration has since reaffirmed and expanded SD policy through its National Security Strategy calling for acceleration of $\mathrm{SD}^{23}$ the Presidential Policy Directive on Global Development calling for promotion of SD internationally, ${ }^{24}$ and incorporating the President's Global Climate Change Initiative, ${ }^{25}$ Global Food Security Initiative, ${ }^{26}$ Global Health Initiative, ${ }^{27}$ President's Climate Action Plan, ${ }^{28}$ the

increasingly come to view a party's refusal to license an expanding list of technologies as creating a conflict with the public interest that justifies government intervention.).

${ }^{19}$ See President's Council on Sustainable Development, NAT'L ARCHIVES \& RECORDS ADMIN., http://clinton4.nara.gov/PCSD/ (last visited Apr. 13, 2015).

${ }_{20}$ See Task Forces, NATL ARCHIVES \& RECORDS ADMIN., http://clinton2.nara.gov/PCSD/tforce/ (last visited Apr. 13, 2015).

${ }^{21}$ See Publications, NAT'L ARCHIVES \& RECORDS ADMIN., http://clinton2.nara.gov/PCSD/Publications/ (last visited Apr. 13, 2015).

${ }^{22}$ See A National Security Strategy for $A$ New Century, NAT'L ARCHIVES \& RECORDS ADMIN. (May 1997) http://dinton2.nara.gov/WH/EOP/NSC/Strategy/. 2010),

${ }^{23}$ See EXEC. OfFice of THE PREsident, National Security Strategy 33-34 (May http://www.whitehouse.gov/sites/default/files/rss_viewer/national_security_strategy.pdf.

${ }^{24}$ See Press Release, President Barack Obama, Fact Sheet: U.S. Global Development Policy (Sept. 22, 2010), http://www.whitehouse.gov/the-press-office/2010/09/22/fact-sheet-us-globaldevelopment-policy.

${ }^{25}$ See EXeC. Office of The President, President Obama's Development Policy and THE GLOBAL ClimATE CHANGE INITIATIVE (2010), available at https://www.whitehouse.gov/sites/default/files/Climate_Fact_Sheet.pdf.

${ }^{26}$ See Exec. OfFice of The President, President Obama's Globat Development POLICY AND GLOBAL FOOD SECURITY (2010), available at https://www.whitehouse.gov/sites/default/files/Food_Security_Fact_Sheet.pdf.

${ }^{27}$ See EXec. Office of The President, President Obama's Global Development POLICY AND GLOBAL HEALTH INITIATIVE (2010), available at https://www.whitehouse.gov/sites/default/files/Global_Health_Fact_Sheet.pdf.

${ }^{28}$ See EXec. OfFice OF THE PRESIDENT, PRESIDENT's Climate Action Plan 9-10 (June 2013), https://www.whitehouse.gov/sites/default/files/image/president27sclimateactionplan.pdf (setting forth, in part, the President's plans for cutting carbon pollution from power plants and for curbing hydrofluorocarbon (HFC) and methane emissions, each of which require EPA participation). 
interagency Partnership for Sustainable Communities, ${ }^{29}$ and the Environmental Justice Strategy. ${ }^{30}$

These White House and federal agency initiatives have encouraged participation by private and public nongovernmental organizations ("NGOs"), such as the International Council for Local Environmental Initiatives ("ICLEI") ${ }^{31}$ and the International City/County Management Association. ${ }^{32}$ While these entities have become leading organizers of local sustainability initiatives in the United States, other national NGOs have also engaged in such endeavors. They include the American Public Works Association, ${ }^{33}$ the American Water Works Association, ${ }^{34}$ the American Planning Association, ${ }^{35}$ the National League of Cities, ${ }^{36}$ and the National Association of Counties. ${ }^{37}$

During the past six-plus years, in furtherance of an environment-first SD agenda, the Obama Administration has ensured that federal agencies directly and indirectly subsidize such entities' activities. For example, the U.S. Department of Housing and Urban Development ("HUD") has promoted ICLEI's Sustainability Planning Toolkit ${ }^{38}$ and Clean Air and

${ }^{29}$ See Partnership for Sustainable Communities, An Interagency Partnership, U.S. DEP'T HousING

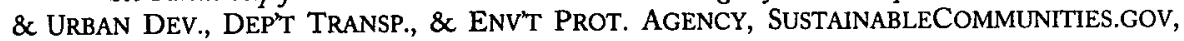
$\mathrm{http}: / /$ www.sustainablecommunities.gov/ (last visited Feb. 21, 2015).

${ }^{30}$ See Environmental Justice Equals Healthy, Sustainable, and Equitable Communities, U.S. ENV'T PROT. AGENCY, http://www.epa.gov/compliance/ej/sustainability/index.html (last updated Aug. 7, 2013).

${ }^{31}$ See Local Initiatives Changed Global Thinking About Sustainable Development, ICLEI - LOCAL GOV'TS FOR SUSTAINABILITY, http://local2012.iclei.org/local-sustainability-study/ (last visited Mar. 13, 2015).

${ }^{32}$ See A Member-Driven Organizational Culture, INT'L CITY/CNTY. MGMT. ASS'N, $\mathrm{http}: / / \mathrm{icma}$.org/en/icma/about/organization_overview (last visited Mar. 13 2015).

${ }_{33}$ See Jennifer Winter, Center for Sustainability, AM. PUB. WORKS ASs'N, http://www.apwa.net/centerforsustainability (last visited Mar. 13, 2015).

${ }^{34}$ See Sustainability, AM. WATER WORKS ASS'N, http://www.awwa.org/about-us/policystatements/policy-statement/articleid/217/sustainability.aspx (last revised June 8, 2014).

${ }_{35}$ See APA Green Team, AM. PLANNING ASS'N, https://www.planning.org/apaataglance/greenteam/ (last visited Feb. 25, 2015).

${ }^{36}$ See Sustainability Strategies, NAT'L LEAGUE OF CitIES Sustainable Cities INST., http://www.sustainablecitiesinstitute.org/topics/water-and-green-infrastructure/green-infrastructure101/gi-sustainability-strategies (last visited Feb. 25, 2015).

${ }^{37}$ See NAT'L ASS'N OF CNTYS. 2012 EMERGING SUSTAINABILITY STRATEGIES IN AMERICA'S COUNTIES available http://www.naco.org/newsroom/pubs/Documents/2012_Emerging_Sustainability_Strategies_Publicatio n.pdf.

${ }^{38}$ See ICLEI - LOCAL GOV'TS FOR SUSTAINABILITY USA, SUSTAINABILITY PLANNING TOOLKIT (2009), 
Climate Protection Software (recently replaced by ICLEI's ClearPath suite of software tools). ${ }^{39}$ The U.S. Environmental Protection Agency ("EPA"), meanwhile, has underwritten and popularized ICLEI's co-authored climate change Adaptation Guidebook ${ }^{40}$ and co-developed the Local Government Greenhouse Gas Protocol. ${ }^{41}$ In addition, HUD and EPA together have funded or supported ICMA's Rural and Sustainable Communities Projects, ${ }^{42}$ Local Government Environmental Assistance Network ("LGEAN"), ${ }^{43}$ and the national Brownfields Conference. ${ }^{44}$ The Obama Administration has remained vigilant in ensuring the federal funding of state and local public and private SD initiatives, including sustainability movements on university campuses, ${ }^{45}$ which is critical to the administration's' success. ${ }^{46}$

\footnotetext{
${ }^{39}$ See Handbook for Estimating Transportation Greenbouse Gases for Integration into the Planning Process, U.S. DEP'T OF TRANSP., FED. HIGHWAY ADMIN., http://www.fhwa.dot.gov/environment/climate_change/mitigation/publications_and_tools/ghg_handbo ok/chapter09.cfm (last updated July 23, 2014) (referring and linking to "ICLEI, Clean Air and Climate Protection (CACP) Software 2009").
}

40 See Impacts and Adaptation - Resources, U.S. ENV'T PROT. AGENCY, http://www.epa.gov/statelocalclimate/state/topics/impacts-adaption.html (last updated April 2, 2014) (citing CTR. FOR SCIENCE IN THE EARTH SYS. (THE ClimATE IMPACTS GRP.) ET AL., PREPARING For Climate CHANGE: A GUIDEBOOK FOR LOCAL, REgIONAL, AND STATE GOVERNMENTS (Sept. 2007)).

${ }^{41}$ See Developing a Greenbouse Gas Inventory - Tools - Inventory Tools, U.S. ENV'T PROT. AGENCY, http://www.epa.gov/statelocalclimate/local/activities/ghg-inventory.html (last updated Sep. 17, 2014) (citing U.S. Community Protocol for Accounting and Reporting of Greenbouse Gas Emissions, ICLEI - LOCAL GOV'TS FOR SUSTAINABILITY USA, http://www.icleiusa.org/tools/ghgprotocol/community-protocol/us-community-protocol-for-accounting-and-reporting-of-greenhousegas-emissions).

${ }^{42}$ See Small Towns, Rural Communities and Sustainability, INT’L CITY/CNTY. MGMT. Ass'N, $\mathrm{http} / / \mathrm{icma} . \mathrm{org} / \mathrm{m} / \mathrm{en} / \mathrm{results} / \mathrm{sustainable}$ _communities/projects/small_towns_rural_communities_and_s ustainability (last visited Mar. 13, 2015).

${ }^{43}$ See Local Government Environmental Assistance Network (LGEAN), INT'L CITY/CNTY. MGMT. Ass'N, http://icma.org/m/en/results/sustainable_communities/projects/lgean (last visited Mar. 13, 2015).

44 See National Brownfields Conference, INT'L CITY/CNTY. MGMT. Ass'N, $\mathrm{http} / / / \mathrm{icma} . o r g / \mathrm{m} / \mathrm{en} / \mathrm{results} /$ sustainable_communities/projects/brownfields_conference (last visited Mar. 13, 2015).

${ }_{45}$ See Rachelle Peterson and Peter W. Wood, Sustainability: Higher Education's New Fundamentalism, National Association of Scholars (March 25, 2015), available at: http://www.nas.org/images/documents/NAS-Sustainability-Digital.pdf ("The EPA alone has spent more than $\$ 333$ million in the last 15 years sponsoring sustainability fellowships, predominantly for college and university professors, ... in addition to another $\$ 60$ million in sustainability research grants. The National Oceanic and Atmospheric Administration records show more than $\$ 3$ billion in grants for climate science research since 1998 (more than $\$ 89$ million in 2014), while the National Institutes of Health has granted in the last four years alone $\$ 28$ million for research on climate change and another $\$ 580$ million on 'Climate-Related Exposures and Conditions.' . . . The National Science Foundation records show more than $\$ 1.7$ billion since 1998 in sustainability research grants. . . The National 


\section{EROSION OF SEPARATION OF POWERS AND THE GROWING JUDICIAL DEFERENCE TO LEGISLATIVE AND EXECUTIVE EXPERTISE}

These SD initiatives have succeeded, in part, because of the evolving structure of our federal government and our national leaders' inability or unwillingness to maintain the Founders' vision of separation of powers. ${ }^{47}$ This has occurred, for example, as the result of the Clinton and Obama Administrations' close oversight, management and control of the federal bureaucracy in furtherance of presidential policy agendas. ${ }^{48}$ This also has occurred as the result of the Congress' prior enactment of ambiguous legislation (including the Clean Air and Water Acts, Endangered Species Act, etc.) delegating broad interpretive authority to the EPA, the U.S. Department of Interior and the National Oceanic and Atmospheric Administration ("NOAA"), and ongoing abdication of its authority to engage in active subsequent substantive review of agency regulations promulgated in implementation of such statutes. ${ }^{49}$ In addition, this has

Endowment for the Arts invested $\$ 2$ million over the same period. . . The disparity in date ranges available in government grant databases makes direct comparisons difficult. But these numbers indicate an average of $\$ 465$ million in federal funding for sustainability and climate change research each yearthough in recent years government funding for climate research has increased substantially.") Id., at $\mathrm{p}$. 15 .

${ }^{46}$ See Leslie Hom, The Making of Local Agenda 21: An Interview with Jeb Brugmann, 7 LOCAL ENV'T 251 (2002); see also ADRIEN LABAYE, ICLEI AND GLOBAL ClIMATE CHANGE: A LOCAL GOVERNMENT'S ORGANIZATIONAL ATTEMPT TO REFRAME THE PROBLEM OF GLOBAL ENVIRONMENTAL CHANGE 53-54 (2010).

${ }^{47}$ See The Federalist Papers (1787), The Library of Congress, available at: http://thomas.loc.gov/home/histdox/fedpapers.html.

${ }^{48}$ See Elena Kagan, Presidential Administration, 114 Harv. L. Rev. 2245 (2000-2001), available at: http:/harvardlawreview.org/wp-content/uploads/pdfs/vol114_kagan.pdf ("argu[ing] that President Clinton, building on a foundation President Reagan laid, increasingly made the regulatory activity of the executive branch agencies into an extension of his own policy and political agenda. He did so, primarily, by exercising directive authority over these agencies and asserting personal ownership of their regulatory activity - demonstrating in the process, against conventional wisdom, that enhanced presidential control over administration can serve pro-regulatory objectives.")

${ }^{49}$ See Congressional Review Act of 1996, Pub. L. No. 104-121, tit. II, subtit. E, 110 Stat. 868874, as amended, codified at 5 U.S.C. 801-808 (2006), available at: http://www.epa.gov/rfa/statute/publ104121.pdf; http://www.gao.gov/legal/congressact/congress.html (enabling Congress to undertake legislative review of 'major' executive agency regulations and to express disapproval by resolution); Richard S. Beth, Disapproval of Regulations by Congress: Procedure Under the Congressional Review Act, Congressional Research Service - CRS Report for Congress RL31160 (Oct. 10, 2001), available at: http://www.senate.gov/CRSReports/crspublish.cfm?pid=\%270E\%2C*P\%5C_\%3D\%22P\%20\%20\%0A; Morton Rosenberg, Congressional Review of Agency Rulemaking: An Update and Assessment of The Congressional Review Act after a Decade, Congressional Research Service (“CRS") Report for Congress RL30116 (May 8, 2008), at CRS-18, 
occurred as the result of the federal judiciary's prior and continued deference to both executive agency implementing regulations deemed to be a permissible (rational) construction/interpretation of the statute and to agencies' underlying SD-focused precautionary science-based decisions, ${ }^{50}$ and because of the judiciary's all-too-frequent ideological adherence to a strict doctrine of constitutional (Article III and prudential) standing in defense of the Executive. ${ }^{51}$ Such erosion in the separation of powers has,

Summary, CRS-1, available at: http://assets.opencrs.com/rpts/RL30116_20080508.pdf (providing an update to a prior CRS Report discussing the Congressional Review Act and noting how "[i]n the 11plus years since its passage, the CRA process has been used sparingly," and that "Lolf a total of 47 joint resolutions of disapproval that bave been introduced to date since April 1996, only one has passed and that one may have been sui generis because of the unique circumstances accompanying its passage") (emphasis added); The Mysteries of the Congressional Review Act, 122 Harv. L. Rev. 2162, 2166-67 (2009), available at: http://cdn.harvardlawreview.org/wpcontent/uploads/pdfs/vol_122_the_mysteries.pdf (('Obviously, the CRA did not accomplish the impossible feat that the Senators' rhetoric claimed for it: reshaping the constitutional separation of powers while still remaining within the Constitution's bounds. The CRA's effect was far moire modest..."); Morton Rosenberg, The Critical Need for Effective Congressional Review of Agency Rules: Background and Considerations for Incremental Reform, A Report Prepared for the Administrative Conference of the United States (July 18, 2012), at p. 11, available at: http://www.acus.gov/sites/default/files/documents/CRA\%20_\%20Final\%20Report.pdf ("As of August 15, 2011, the Comptroller General had submitted reports pursuant to Section 801(a)(2)(A) to Congress on 1,029 major rules.[fn] In addition, GAO had cataloged the submission of 56,668 non-major rules as required by Section 801 (a)(1)(A). To date, 72 joint resolutions of disapproval have been introduced relating to 49 rules. One rule, the Occupational Safety and Health Administration's ("OSHA") ergonomics standard, was disapproved in March 2001, an action that some believe to be unique to the circumstances of its passage") (emphasis added).

${ }^{50}$ See, e.g., Coalition for Responsible Regulation, Inc. v. EPA, 684 F.3d 102, 120-121 (D.C. Cir. 2012) (per curiam) ("As we have stated before in reviewing the science-based decisions of agencies such as EPA, '[a]lthough we perform a searching and careful inquiry into the facts underlying the agency's decisions, we will presume the validity of agency action as long as a rational basis for it is presented.' $A m$. Farm Bureau Fed'n v. EPA, 55.9 F.3d 512, 519 (D.C. Cir. 2009). In so doing, 'we give an extreme degree of deference to the agency when it is evaluating scientific data within its technical expertise.' Id. [...] If a statute is 'precautionary in nature' and 'designed to protect the public health', and the relevant evidence is 'difficult to come by, uncertain, or conflicting because it is on the frontiers of scientific knowledge,' EPA need not provide 'rigorous step-by-step proof of cause and effect' to support an endangerment finding. Ethyl Corp. v. EPA, 541 F.2d 1, 28 (D.C. Cir. 1976)."). See also Emily Hammond Meazell, Super Deference, the Science Obsession, and Judicial Review as Translation of Agency Science, 109 Mich. L. Rev. 733 (2011) (arguing that although this "super-deference" principle seems appealing because it is supported by basic notions of institutional competence and accommodates a natural judicial tendency to avoid deep encounters with science. But it stands in stark tension with the expectation that courts must reinforce administrative-law values like participation, transparency, and deliberation. And it fails to further the legitimizing function of incorporating the best possible science into institutional decision making.").

${ }_{51}$ See Lawrence A. Kogan, Revitalizing the Information Quality Act as a Procedural Cure for Unsound Regulatory Science: A Greenbouse Gas Rulemaking Case Study, Washington Legal Foundation Working Paper No. 191 (Feb. 2015), at pp. 30-32, 36-36 (and sources cited therein), available at: http://www.wlf.org/upload/legalstudies/workingpaper/2015Kogan.pdf; Institute for Trade, Standards and Sustainable Development, Placing APAIQA Jurisprudence into Proper Perspective - Three Possible Prudential Uses of the Separation of Powers Doctrine to Curtail Standing, available at: 
arguably, thereby contributed to the Executive's exploitation of conflicting notions of evolving federalism, as discussed below.

\section{FEDERALISM JURISPRUDENCE SHOWS HOW LOCAL SUSTAINABLE DEVELOPMENT INITIATIVES CAN ULTIMATELY STRENGTHEN EXECUTIVE AUTHORITY}

The Obama Administration, like the Clinton Administration, has learned from U.S. federalism jurisprudence how to strengthen the Executive Branch's hand in state and local SD policymaking without encountering much, if any, congressional or judicial resistance.

\section{A. Exploiting Conflicting Notions of Federalism.}

The concept of federalism connotes a "system of power-sharing" between a larger political unit and its smaller and partially independent political subdivisions. ${ }^{52}$ More specifically, the Obama Administration has relied on remnants of New Deal-era Modern Federalism, ${ }^{53}$ which expanded rapidly during the period of President Johnson's "Great Society" ${ }^{24}$ with the assistance of former U.S. Supreme Court Chief Justice Earl Warren. New Deal-era Modern Federalism reflected a political consensus "mandating

https://nebula.wsimg.com/722191b930b26410de9fc74d0921f2d1?AccessKeyId=39A2DC689E4CA87 C906D\&disposition $=0$ \&alloworigin $=1$.

${ }^{52}$ See Bradley C. Bobertz, Blowing the Whistle on Postmodern Federalism, 21 PACE ENVTL. L. REV. 83, 88 (2004).

${ }^{53}$ See Adam Cohen, Op-Ed, What's New in the Legal World? A Growing Campaign to Undo the New Deal, N.Y. Times (Dec. http://www.nytimes.com/2004/12/14/opinion/14tue4.html?_r=1\& (discussing, in part, how New Deal era laws and programs had had 'an expansive view of Congress' power to legislate in the public interest."). This era arguably commenced on April 12, 1937, with the U.S. Supreme Court's decision in Nat'l Labor Relations Bd v. Jones E Laughlin Steel Corp., 301 U.S. 1 (1937), in which "the Court abandoned an overly restrictive understanding of the commerce power." Bobertz, supra note 52, at 94 . It thereafter proceeded to uphold the constitutionality of most congressional actions, including enacting environmental laws, under the Commerce Clause and Section V of the Constitution's Fourteenth Amendment. For example, in United States v. Carolene Products, 304 U.S. 144, 152 (1938), the U.S. Supreme Court had held that economic "regulatory legislation affecting ordinary commercial transactions [was] not to be pronounced unconstitutional unless in the light of the facts made known or generally assumed it [was] of such a character as to preclude the assumption that it rest[ed] upon some rational basis within the knowledge and experience of the legislators." Id.

${ }_{54}$ See Lyndon $B$. Jobnson, THE WHITE HOUSE, http://www.whitehouse.gov/about/presidents/lyndonbjohnson (last visited Apr. 16, 2015). 
judicial restraint and deference to Congressional and Executive legislative and policy judgments." ${ }^{55}$

The U.S. Supreme Court, led by Chief Justice Warren Burger, upheld this consensus approximately a half a century later to limit judicial oversight of legislative, and consequently, executive, decision-making in Chevron U.S.A., Inc. v. Natural Resources Defense Council, Inc. In Chevron, the Court held that where:

Congress has not directly addressed the precise question at issue, the court does not simply impose its own construction on the statute, as would be necessary in the absence of administrative interpretation. Rather, if the statute is silent or ambiguous ... the question for the court is whether the agency's answer is based on a permissible construction of the statute. ${ }^{56}$

\section{B. Legislative and Executive Preemption of State Interests}

Consistent with New Deal-era Modern Federalism, earlier Supreme Courts dating back to 1941 also referred to Tenth Amendment states' rights ${ }^{57}$ as the "residue of state sovereignty." ${ }^{58}$ For example, in United States v. Darby, the Court construed the Tenth Amendment "as not depriving the national government of authority to resort to all means for the exercise of a granted power which are appropriate and plainly adapted to the permitted end." ${ }^{\text {"9 }}$ More than half a century later in Crosby v. NFTC and American Insurance Ass'n v. Garamendi, the Supreme Court, led by Chief Justice William Rehnquist, upheld this consensus, which limited the states' ability

${ }^{55}$ See Simon Lazarus, John Roberts' Supreme Court Is the Most Meddlesome in U.S. History: How Radical Libertarianism is Reshaping the Bench, NEW REPUBLIC (July 10, 2014), http://www.newrepublic.com/article/118648/john-roberts-supreme-court-most-meddlesome-us-history (referring to this phenomenon as "the post-New Deal consensus").

${ }^{56}$ Chevron, U.S.A., Inc. v. Nat. Resources Def. Council, 467 U.S. 837, 843 (1984).

${ }^{57}$ U.S. CONST. amend. X ("The powers not delegated to the United States by the Constitution, nor prohibited by it to the states, are reserved to the states respectively, or to the people.").

${ }^{58}$ See Bobertz, supra note 52, at 94.

${ }^{59}$ United States v. Darby, 312 U.S. 100, 124 (1941). 
to enact laws that directly interfered or conflicted with Congress' and the President's respective authorities to conduct foreign affairs. ${ }^{60}$

In Crosby, Massachusetts enacted a law precluding state and local government agencies from conducting transactions with companies doing business in Burma, notwithstanding prior legislative and executive actions to restrict financing or other forms of direct non-humanitarian aid to Burma and to prohibit new investment in Burma by 'United States persons. $^{6162}$ The Supreme Court held that since the Massachusetts law conflicted with these actions, and legislation vested in the President the discretion to suspend or continue sanctions depending on Burma's progress on human rights in the interest of national security, the Constitution's Supremacy Clause preempted the state law. ${ }^{63}$

In Garamendi, California enacted the Holocaust Victim Insurance Relief Act (HVIRA), "requiring any insurer doing business in the state to disclose information about all policies sold in Europe between 1920 and 1945. ${ }^{n 64}$ The Supreme Court held the California law unconstitutional on preemption grounds because there was "a sufficiently clear conflict between HVIRA and the consistent presidential policy to encourage voluntary settlement funds and disclosure of policy information [via executive agreements with Germany, Austria, and France] in preference to litigation or coercive sanctions. ${ }^{n 65}$ The Court reasoned that, "the President possesses considerable independent constitutional authority to act on behalf of the United States on international issues... and conflict with the exercise of that

${ }^{60}$ See Crosby v. Nat'l Foreign Trade Council, 530 U.S. 363 (2000); see also Am. Ins. Ass'n v. Garamendi, 539 U.S. 396 (2003).

${ }^{61}$ MiChael F. MARTIN, CONG. RESEARCH SERV., R42939, U.S. SANCTIONS ON BURMA: ISSUES FOR THE 113TH CONGRESS 7-8 (2013), available at http://www.fas.org/sgp/crs/row/R42939.pdf ("During the 1990s, Congress considered a number of bills and resolutions calling for additional sanctions on Burma. Most of those measures failed to emerge from committee, with a few notable exceptions [...] Section 570 of the Omnibus Consolidated Appropriations Act, 1997 (P.L. 104-208) [inter alia] ...required the President to prohibit new investments in Burma by U.S. persons.").

${ }^{62}$ Crosby v. Nat'l Foreign Trade Council, 530 U.S. 363, 370 ("On May 20, 1997, the President issued the Burma Executive Order, Exec. Order No. 13047, 3 CFR 202 (1997 Comp.).").

${ }^{63}$ Id. at 388.

${ }^{64}$ See Garamendi, 539 U.S. at 397.

${ }^{65}$ Id. at 398, 421; See also id. at 427 (concluding that California's effort "to use an iron fist where the President ha[d] consistently chosen kid gloves...[had stood] in the way of [the President's] diplomatic objectives. ${ }^{\text {) }) . ~}$ 
authority is a comparably good reason to find preemption of state law." The Court effectively categorized the result in Garamendi as "preemption by executive conduct in foreign affairs." ${ }^{\text {67 }}$

The Supreme Court's decisions in Crosby and Garamendi have influenced lower federal court rulings, such as the Illinois Federal District Court's decision in NFTC v. Giannoulias. ${ }^{68}$ In Giannoulias, the court issued a permanent injunction precluding the State of Illinois from enforcing the Illinois Act to End Atrocities and Terrorism in the Sudan ${ }^{69}$ because it found that the law conflicted with and was broader than the Federal Sudan policy. ${ }^{70}$

\section{Evolved Federalism and Permitted Assertion of States' Rights in Domestic Affairs}

The Obama Administration has also relied, in part, on a series of Supreme Court decisions strengthening a state's right to adopt international SD initiatives that compliment, and even further, related Executive Branch policies. In doing so, it has learned how to harness the Supreme Court's more recent anti-New Deal-era post-modern federalism agend $a^{71}$ pursued by former Chief Justice Rehnquist and current Chief Justice John Roberts, which is intended to limit an adverse Congress' preemption of conflicting state laws. ${ }^{72}$

${ }^{66}$ Id. at 425 .

${ }^{67}$ Id. at 428.

${ }^{68}$ See Nat'l Foreign Trade Council v. Giannoulias, 523 F. Supp. 2d 731, 741 (N.D. Ill. 2007).

${ }^{69}$ The Illinois Act had prohibited certain investments in the government of Sudan and companies doing business in or with Sudan because of human rights atrocities the Government of Sudan was known to have committed.

${ }^{70}$ See Giannoulias, 523 F. Supp. 2d at 741-42.

${ }^{71}$ See Bradley C. Bobertz, Blowing the Whistle on Postmodern Federalism, 21 PACE ENVTL. L. REV. 83, 90, 94 (2004) (discussing how the era of Post-Modern Federalism is said to have commenced on April 25, 1995, with the U.S. Supreme Court's decision in United States v. Lopez, and how, during the past twenty years, the U.S. Supreme Court has effectively abandoned the "presumption of legislative rationality" that federal courts had previously employed beginning in the New Deal Era to uphold the constitutionality of "most forms of congressional action.").

${ }^{72}$ See Adam Cohen, Op-Ed., What's New in the Legal World? A Growing Campaign to Undo the New Deal, N.Y. TIMES, Dec. http://www.nytimes.com/2004/12/14/opinion/14tue4.html?_r=0 (discussing, in part, how "States' rights conservatives'...attacks on the post-1937 view of the Constitution are becoming more mainstream among Republicans," and how "the Supreme Court['s] [likely rightward] drift[]...in the [ensuing] four years [...] could not only roll back Congress's Commerce Clause powers, but also revive other dangerous doctrines."); see also Simon Lazanus, Jobn Roberts' Supreme Court Is the Most Meddlesome in U.S. History: 
For example, in New York $v$. United States, ${ }^{73}$ the State of New York challenged the amended Low-Level Radioactive Waste Disposal Act of 1980 which "required that every state clean up its nuclear waste by 1996."74 The Court held that "Congress may not simply 'commandee[r] the legislative processes of the States by directly compelling them to enact and enforce a federal regulatory program." ${ }^{75}$ In United States v. Lopez, ${ }^{76}$ respondents challenged the Gun-Free School Zones Act of 1990, which makes the possession of firearms in local school zones unlawful. The Court held that the statute exceeded Congress' authority under the Constitution's Commerce Clause. It reasoned that the statute was a criminal statute and that the possession of firearms in local school zones did not constitute "an economic activity that might, through repetition elsewhere, have a substantial effect on interstate commerce. ${ }^{177}$ In United States v. Morrison, ${ }^{78}$ the Court held that the Violence Against Women Act of 1994, which "provide[d] a federal civil remedy for the victims of gender-motivated violence," was unconstitutional under the Commerce Clause and the Fourteenth Amendment. The Court held that "the statute did not regulate an activity that substantially affected interstate commerce[,] nor did it redress harm caused by the state." 79 It concluded that, "under our federal system," the criminal remedy for rape that the petitioner sought "must be provided by the Commonwealth of Virginia and not by the United States." 8081

How Radical Libertarianism is Reshaping the Bench. THE NEW REPUBLIC (July 10, 2014), http://www.newrepublic.com/article/118648/john-roberts-supreme-court-most-meddlesome-us-history (last visited Mar. 11, 2015) (discussing how the Roberts Court had reviewed "important decisions about regulation and the economy this term" by addressing "below-the-radar questions of statutory interpretation and judicial deference to agency decisions" in an effort to "replac[e] Carolene Products-style rational basis deference with active judicial micro-management," citing its review of "President Obama's global warming program" as one of several examples.).

${ }^{73}$ See New York v. United States, 505 U.S. 144 (1992).

${ }^{74} I d$. at $150-51$.

${ }^{75}$ Id. at 161 (quoting Hodel v. Virginia Surface Mining \& Reclamation Assn., Inc., 452 U. S. $264,288(1981))$.

${ }^{76}$ See United States v. Lopez, 514 U.S. 549 (1995).

7 See Oral Opinion Announcement, United States v. Lopez, 514 U.S. 549 (1995) (No. 93-1260), available at http://www.oyez.org/cases/1990-1999/1994/1994_93_1260.

${ }^{78} \mathrm{See}$ United States v. Morrison, 529 U.S. 598 (2000).

${ }^{79}$ See Oral Opinion Announcement, United States v. Morrison, 529 U.S. 598 (2000) (No. 99-5), available at http://www.oyez.org/cases/1990-1999/1999/1999_99_5.

${ }^{80} \mathrm{Id}$. 


\section{Evolved Federalism and Permitted Assertion of States' Rights in Foreign Affairs}

The Obama Administration also relies on the concurring opinion of Justice John Marshall Harlan, II in Zschernig v. Miller, ${ }^{82}$ the subsequent nonbinding discussion of that opinion in American Insurance Association. $v$. Garamendi $^{83}$, and the more recent holding in Medellin v. Texas. ${ }^{84}$ Collectively, these cases strengthen states' ability to adopt local SD initiatives, over which the President ultimately has final say, that can help shape United States foreign affairs, so long as they remain consistent with executive branch policymaking.

Zschernig involved an Oregon statute providing for the escheat of personal property belonging to nonresident aliens who died intestate unless certain prescribed conditions were satisfied. ${ }^{85}$ The majority opinion, written by Justice William Douglas, held that the Oregon law was unconstitutional because it entailed the "kind of state involvement in foreign affairs and international relations $[\ldots]$ which the Constitution entrusts solely to the Federal Government." ${ }^{86}$ Although Justice Harlan concurred with the Court's conclusion that a treaty, by virtue of the Constitution's Supremacy Clause, preempted the Oregon law, ${ }^{87}$ he rejected its rationale. Justice Harlan's concurring opinion argued that the Oregon statute was constitutional based on prior Court precedents "establish[ing] that, in the absence of a conflicting federal policy or violation of the express mandates of the Constitution, the States may legislate in areas of their traditional

${ }^{81}$ See also Erwin Chemerinsky, Keynote Address: Laboratories of Democracy: Federalism and State Law Independency Speech, 41 WILLAMETTE L. REV. 827, 833-35 (2005) (generally discussing federalism issues and limits to Congress' power under the Fourteenth Amendment).

${ }^{82}$ See Zschernig v. Miller, 389 U. S. 429, 443-62 (1968).

${ }^{83}$ See Garamendi, 539 U.S. 396.

${ }^{84}$ See Medellin v. Texas, 552 U.S. 491 (2008).

${ }^{85}$ Zschernig, 389 U.S. at 429.

${ }^{86} \mathrm{Id}$. at 436; see also id. at 442-43 ("Our system of government is such that the interest of the cities, counties, and states, no less than the interest of the people of the whole nation, imperatively requires that federal power in the field affecting foreign relations be left entirely free from local interference ... [and] the conduct of our foreign affairs is entrusted under the Constitution to the National Government, not to the probate courts of the several States.").

${ }^{87} \mathrm{Id}$. at 462 ("I therefore concur in the judgment of the Court upon the sole ground that the application of the Oregon statute in this case conflicts with the 1923 Treaty of Friendship, Commerce and Consular Rights with Germany."). 
competence even though their statutes may have an incidental effect on foreign relations" (emphasis added). ${ }^{88}$

In Garimendi, the majority opinion examined how the rule Justice Harlan articulated in Zschernig would apply. The Court, in dicta, opined where "state legislation will produce something more than incidental effect in conflict with express foreign policy of the National Government," but nevertheless falls "within 'areas of...traditional competence' $[, \ldots$.$] it would be$ reasonable to consider the strength of the state interest, judged by standards of traditional practice, when deciding how serious a conflict must be shown before declaring the state law preempted" (emphasis added) ${ }^{89}$ Several legal commentators have since concluded that the Court effectively established a new "balancing test comparing the degree of conflict with the extent of the state's interest. ${ }^{\text {" }}$ In their view, Justice Harlan's test, which required a "twostep inquiry," 91 did not strengthen states' rights. Rather, the test theoretically broadened the Court's holding in Zscherning by eliminating “its inquiry into the 'direct' or 'incidental' effects of state laws on foreign relations," 92 indirectly expanding the power of the President through executive agreements to unilaterally preempt state laws (without congressional approval) that conflict with his or her foreign affairs policy. ${ }^{93}$

${ }^{88} \mathrm{Id}$. at 459 (emphasis added) ("Oregon ha[d] so legislated in the course of regulating the descent and distribution of estates of Oregon decedents, a matter traditionally within the power of a State"); see also id. n.25.

${ }^{89}$ Garamendi, 539 U.S. at 420 (emphasis added); see also id. n.11.

${ }^{90}$ Brannon P. Denning \& Michael D. Ramsey, American Insurance Association v. Garamendi and Executive Preemption in Foreign Affairs, 46 WM. \& MARY L. REV. 825, 928 (2004), available at http://scholarship.law.wm.edu/cgi/viewcontent.cgi?article=1276\&context=wmlr; see also Alexandria $\mathrm{R}$. Strauss, Supremacy of the Supremacy Clause: A Garamendi-Based Framework for Assessing State Law That Intersects with U.S. Foreign Policy, 83 FORDHAM L. REV. 417, 434-35 (2014).

${ }^{91}$ Initially, a court should question "whether the state is 'tak[ing] a position on a matter of foreign policy' without a 'serious claim to be addressing a traditional state responsibility." Denning \& Ramsey, supra note 90 , at 926 . In such a case, “Zschernig's dormant foreign affairs exclusion might apply" because the state's actions would fall outside the protection of the Constitution which "vest[s] . . power over 'foreign policy' in the federal government" and, more specifically, in the President. Denning \& Ramsey, supra note 90 , at 926-27. If the state satisfies the threshold inquiry, a court should then undertake "a conflict preemption analysis (with federal policy defined by the executive branch)" in which "the strength and clarity required of the conflict will vary with the strength of the state's interest" (i.e., the greater the state's interest, the greater the conflict necessary to trigger preemption); Denning \& Ramsey, supra note 90 , at 928 .

${ }^{92}$ Denning \& Ramsey, supra note 90, at 929.

${ }^{93}$ Id. at $939-41$. 
In Medellin $v$. Texas, ${ }^{94}$ the Court considered whether the State of Texas was obliged to enforce an International Court of Justice ruling ${ }^{95}$ which directed the United States "to provide 'review and reconsideration of the [criminal] convictions and [death] sentences of the Mexican nationals" 96 issued under Texas law in circumstances where petitioners failed to file their claims (writs of habeas corpus) under the Vienna Convention on Consular Relations in a timely manner. ${ }^{97}$ After Avena, a Presidential Memorandum was issued and sought to influence ${ }^{98}$ how the United States would 'discharge its international obligations' under Avena 'by having State courts give effect to the decision." 99 The Supreme Court in Medellin held "that neither Avena nor the President's Memorandum constitute[d] directly enforceable federal law that pre-empts state limitations on the filing of successive habeas petitions." ${ }^{100}$ The Court reasoned that joint action by the executive and legislative branches was necessary to give "domestic effect to an international treaty obligation."101 Notwithstanding the Court's holding, Justice Stevens, in his concurring opinion, implored the State of Texas to recognize the critical role it and other states play "in determining the nature and scope of U.S. compliance with its Vienna Convention obligations," ${ }^{102}$ and in "protecting the honor and integrity of the Nation" in international affairs more generally. ${ }^{103}$

\footnotetext{
${ }^{94}$ See Medellin, 552 U.S. 491.

${ }^{95}$ See Case Concerning Avena and Other Mexican Nationals (Mex. v. U.S.), 2004 I.C.J. 12 (Mar. $31)$.

${ }^{96}$ Medellin, 552 U.S. at 502-03 (quoting Avena, 2004 I.C.J. at 72).

${ }^{97} \mathrm{Id}$. at 502 .

${ }^{98}$ See id. at 536 (Stevens, J., concurring) ("By issuing a memorandum declaring that state courts should give effect to the judgment in Avena, the President made a commendable attempt to induce the States to discharge the Nation's obligation.").

${ }^{99}$ Id. at 498 (quoting Memorandum from President George W. Bush to the U.S. Attorney General Alberto Gonzalez (Feb. 28, 2005).

${ }^{100} \mathrm{Id}$. at $498-99$.

${ }^{101} \mathrm{Id}$. at 527.

${ }^{102}$ Robert Ahdieh, Foreign Affairs, International Law, and the New Federalism: Lessons From Coordination, 73 MO. L. REV. 1185, 1195 (2008).

${ }^{103}$ Medellin, 552 U.S. at 536 (Stevens, J., concurring) ('Under the express terms of the Supremacy Clause, the United States' obligation to 'undertak[e] to comply' with the ICJ's decision falls on each of the States as well as the Federal Government. One consequence of our form of government is that sometimes States must shoulder the primary responsibility for protecting the honor and integrity of the Nation. Texas' duty in this respect is all the greater since it was Texas that - by failing to provide consular notice in accordance with the Vienna Convention - ensnared the United States in the current controversy. Having already put the Nation in breach of one treaty, it is now up to Texas to prevent the breach of another.").
} 


\section{EXAMPLES OF STATE AND LOCAL SUSTAINABLE DEVELOPMENT INITIATIVES ENABLED BY EVOLVING FEDERALISM JURISPRUDENCE}

To recall, evolving Supreme Court federalism jurisprudence has arguably encouraged subnational governments to incorporate a number of domestic and international SD principles into state and local regional compacts, development plans, codes, ordinances, standards and community initiatives, and consequently, to make an impact upon domestic and foreign affairs. The following examples illustrate this point.

Dissatisfied with the failure of the United States to ratify the United Nations Convention on the Elimination of All Forms of Discrimination Against Women ("CEDAW") three cities-Berkeley (2012), Los Angeles (2004), and San Francisco (2003) ${ }^{104}$-have implemented local ordinances that incorporate the provisions of CEDAW into local law (known as "CEDAW ordinances"). These ordinances address discrimination against women broadly, and more specifically, prevention of violence against women. ${ }^{105}$ The Obama Administration has expressed its support for local

${ }^{104}$ See Rita Maran, CEDAW Goes Local in California - and Beyond?, INTLAWGRRLS (Dec. 7, 2012, 11:24 AM), http://www.intlawgrrls.com/2012/12/cedaw-goes-local-in-california-and.html (discussing how, on March 17, 2012, the City of Berkeley, California adopted Ordinance 7,224-N.S., which "added Chapter 13.20, 'Adopting the Operative Principles of the United Nations Convention on the Elimination of All Forms of Discrimination against Women,' to the Berkeley Municipal Code."); BERKEleY, CAL., MUNICIPAL CODE Title 13, div. II, ch. 13.20 (2012), available at http://codepublishing.com/CA/Berkeley/cgi/NewSmartCompile.pl?path=Berkeley13/Berkeley1320/Ber keley1320090.html; see HOPE LEWIS, "NEW" HuMAN RIGHTS: U.S. AMBIVALENCE TOWARD THE INTERNATIONAL ECONOMIC AND SOCIAL RIGHTS FRAMEWORK, in BRINGING HUMAN RIGHTS HOME 1, 138-39 (Cynthia Soohoo et al. eds., Greenwood Publishing Group 2008), available at https://books.google.com/books (discussing how, during December 2003, "the Los Angeles City Council unanimously passed an ordinance to provide for local implementation of CEDAW.); see CEDAW in the United States: Why a Treaty for the Rights of Women?, WOMEN'S ENV'T AND DEV. ORG., http://www.wedo.org/wp-content/uploads/cedaw-factsheet.pdf (last visited Apr. 15, 2015) ("[T]he city of San Francisco, California, enacted a local ordinance in 1998 based on the convention's principles. The ordinance requires the city to protect women's human rights, including the elimination of discrimination against women and girls."); Gretchen Sidhu, San Francisco Plunges Abead in Adopting a Cedaw Treaty Of Its Own, CHI. TRIB. (Aug. 2, 1998), http://articles.chicagotribune.com/1998-0802/features/9808020347_1_cedaw-discrimination-city-agencies.

${ }^{105}$ See Columbia Law School Human Rights Inst. and Univ. of Miami School of Law Human Rights Clinic, Recognizing Freedom From Domestic Violence and Violence Against Women as a Fundamental Human Right: Local Resolutions, Presidential Proclamations, and Otber Statements of Principle, at 2 (Nov. 25, 2014), available at http://www.law.miami.edu/human-rights-clinic/pdf/2014/local-resolutions2014.pdf. 
implementation of CEDAW. ${ }^{106} \mathrm{~A}$ number of other municipalities have shown support for U.S. ratification of CEDAW by adopted CEDAW resolutions based on the model proposed by the U.S. Conference of Mayors ${ }^{107}$ calling for city councils to adopt ordinances incorporating CEDAW principles into local law.

During May 2003, former New York Governor George Pataki invited northeastern states to join New York in a regional market for greenhouse gas reductions. During February 2006, he announced the signing of a regional Memorandum of Understanding for the Regional Greenhouse Gas Initiative ("RGGI"), a mandatory agreement entered into initially by seven northeastern states (New York, Connecticut, Delaware, Maine, New Hampshire, New Jersey, and Vermont). The RGGI cooperative agreed "to implement a [mandatory] cap-and-trade program to lower carbon dioxide (CO2) emissions." ${ }^{108}$ During November 2007, the RGGI “"nonprofit corporation formed to provide technical and scientific advisory services' to all participating RGGI states 'in the development and implementation of the CO2 Budget Trading Program,' announced that the nation's first auction of carbon offset credits and allowances [would take place in 2008.] ${ }^{109}$ As of 2014, nine northeastern states are participating in RGGI. ${ }^{110}$ RGGI's apparent success has spawned the development of other interstate cooperative climate initiatives, including the Western Climate Initiative, the

${ }^{106}$ See CEDAW: US Ratification and Local Implementation Efforts, BERKLEY L. UNIV. OF CAL., https://www.law.berkeley.edu/8285.htm (last visited Apr. 15, 2015).

107 See 2014 Adopted Resolutions - In Support of Cities For CEDAW Initiative and Encouraging Cities to Implement the Principles of the Un Convention on the Elimination of all Forms of Discrimination Against Women, 82nd Annual Meeting of the U.S. Conf. of Mayors (June 2014), available at $\mathrm{http} / /$ www.usmayors.org/resolutions/82nd_Conference/csj18.asp.

${ }^{108}$ Lawrence A. Kogan, Exporting Precaution: How Europe's Risk-Free Regulatory Agenda Threatens American Free Enterprise, WASH. LEGAL FOUND. MONOGRAPH, 1, 54-60 (Nov. 2005), available at http://www.wlf.org/publishing/publication_detail.asp?id=1701; see also Press Release, N.Y. Office of the Governor, N.Y. Gov. Pataki Announces Power Plant CO2 Emissions Agreement, (Feb. 17, 2006), available at http://www.pollutiononline.com/doc/ny-gov-pataki-announces-power-plant-co2-emiss0001.

${ }^{109}$ See Lawrence A. Kogan, The Extra-WTO Precautionary Principle: One European 'Fashion' Export the U.S. Can Do Without, 17 TEMP. POL. \& CIV. RTS. L. REV. 491, 523 (2008).

${ }^{110}$ During 2011, ten states had been participating in RGGI: Connecticut, Delaware, Maine, Maryland, Massachusetts, New Hampshire, New Jersey, New York, Rhode Island, and Vermont. However, on November 29, 2011, New Jersey withdrew from the MOU, effective January 1, 2012; see Program Design Archive, Regional Greenhouse Gas Initiative, http://www.rggi.org/design/history; see also Program Design, REG'L GREENHOUSE GAS INITIATIVE, http://www.rggi.org/design (last visited Apr. 15, 2015). 
Pacific Coast Collaborative, the Midwest Greenhouse Gas Reduction Accord, the Transportation and Climate Initiative, and North America $2050 .^{111}$

At odds with Congress' failure to adopt national climate change legislation, the U.S. Conference of Mayors (USCM) crafted a Climate Protection Agreement in 2005. It encouraged "mayors to 'meet or exceed the Kyoto Protocol targets... in their own operations and communities' through initiatives such as retrofitting city facilities, promoting mass transit, and maintaining healthy urban forests." ${ }^{112}$ It also "called upon federal and state governments to comply with Kyoto targets and [...] urged Congress to pass bipartisan legislation to create an emissions trading system and clear emissions limits' for greenhouse gases." 113 As of 2014, "1060 mayors from the 50 states, the District of Columbia and Puerto Rico, representing a total population of over $88,962,982$ citizens," have endorsed the agreement. ${ }^{114}$

During 2005, eight states (Illinois, Indiana, Michigan, Minnesota, New York, Ohio, Pennsylvania and Wisconsin) and two Canadian provinces (Ontario and Quebec), concerned about trans-boundary water pollution, entered into two Great Lakes Agreements that regulated water diverted from the Great Lakes. ${ }^{115}$ They included the Great Lakes

111 See Multistate Climate Initiatives, CTR. FOR ClIMATE AND ENERGY SOLUTIONS, http://www.c2es.org/us-states-regions/regional-climate-initiatives (last visited Apr. 15, 2015). C2ES is likely funded, in part, by Barclays Capital, Northeast Utilities, Royal Dutch Shell, and General Electric Company. See About: Board of Directors, CTR. FOR Climate AND ENERGY SOLUTIONS, http://www.c2es.org/about/board (last visited Apr. 15, 2015).

${ }^{112}$ See Judith Resnik et al., Ratifying Kyoto at the Local Level: Sovereigntism, Federalism, and Translocal Organizations of Government Actors (TOGAs), 50 ARIZ. L. REV. 709, 718 (2008).

${ }^{113} \mathrm{Id}$. at 718; The U.S. Conf. of Mayors, The U.S. Mayors Climate Protection Agreement, http:/www.usmayors.org/climateprotection/documents/mcpagreement.pdf; Robert Adieh, Foreign Affairs, International Law, and the New Federalism: Lessons from Coordination, 73 MO. L. REV. 1185, 1193 (2008).

${ }^{114}$ See Mayors' Climate Prot. Ctr., List of Participating Mayors, THE U.S. CONF. OF MAYORS, http://www.usmayors.org/dimateprotection/list.asp (last viewed Apr. 15, 2015).

${ }^{115}$ Resnik, et al., supra note 112, at 719-20. 
Sustainable Waters Resources Agreement, ${ }^{116} 117$ and the Great Lakes -St. Lawrence River Basin Water Resources Compact. ${ }^{118}$

Unhappy with the Illinois federal district court's adverse ruling in National Foreign Trade Council v. Giannoulias, the Illinois, Arizona, California, Louisiana, and New Jersey, along with the U.S. Conference of Mayors, successfully lobbied Congress to pass the Sudan Accountability \& Divestment Act of 2007 ("SADA"), which was enacted into law on, December 31, 2007.119 "SADA explicitly authorize[d] state and local divestment measures against Sudan," which influenced both U.S. domestic and foreign policy. ${ }^{120}$

In addition to these illustrative examples, since 2005, U.S. state and local governments have proposed and/or adopted numerous other SDrelated initiatives, many of which have been modeled after similar European Union initiatives and incorporated into local law. ${ }^{121}$ All of these SD initiatives are premised on Europe's post-modernist precautionary principle, and they are intended, in the absence of causal evidence of harm to human health and the environment, to ensure environmental protection of the air, oceans, and domestic navigable waters and to curtail the use of intrinsically harmful substances, products, technologies and industrial activities. ${ }^{122}$ These include: 1) biotech-related food, feed, and seed products and technologies; 2) hazardous substances such as high volume toxic chemicals, cosmetics, brominated flame retardants and the products containing them, metals found in appliances and electronics without the collection, recycling, and disposal of such e-waste; and 3) fossil fuels and fossil-fuel-derivatives, in favor of renewable sources of solar, wind and biomass energy. ${ }^{123}$

${ }^{116}$ See The Great Lakes-St. Lawrence River Basin Sustainable Water Resources Agreement, COUNCIL OF GREAT LAKES GOVERNORS (Dec. 13, 2005), http://www.cglg.org/projects/water/docs/12-1305/great_lakes-st_lawrence_river_basin_sustainable_water_resources_agreement.pdf.

${ }^{117}$ See also Agreements, GREAT LAKES - ST. LAWRENCE WATER RES. REG'L BODY (2007), http://www.glslregionalbody.org/GLSLRBAgreements.aspx.

${ }^{118}$ Id.; see also The Great Lakes-St. Lawrence River Basin Water Resources Compact, GREAT LAKES -

ST. LAWRENCE WATER RES. REG'L BODY (Dec. 13, 2005), http://www.glslregionalbody.org/Docs/Agreements/Great_Lakes-

St_Lawrence_River_Basin_Water_Resources_Compact.pdf.

${ }^{119}$ See Adieh, supra note 113 , at 1196.

${ }^{120} I d$.

${ }^{121}$ See Kogan, The Extra-WTO Precautionary Principle, supra note 109, at 491.

${ }^{122}$ Id. at 1,3 .

${ }^{123}$ See id. at 1, 44, 50; Kogan, The Extra-WTO Precautionary Principle, supra note 109, at 533. 
Lastly, the traditional "dominance and control" local authorities have exercised over land use and zoning has begun to wane. ${ }^{124}$ State and city governments have increasingly commenced climate change and other SDrelated initiatives that have resulted in the promotion and mandating of "green building' development," the "overrid[ing of] local zoning laws that interfere with green development," and the invalidation of "local zoning restrictions that limit the ability of landowners to use solar panels, wind turbines, and other sources of renewable energy." 125

\section{CONCLUSION: LOCAL SUSTAINABILITY INITIATIVES POTENTIALLY INCREASE EXECUTIVE AUTHORITY AND STATES' RIGHTS AT THE EXPENSE OF INDIVIDUAL LIBERTY}

The Supreme Court, in New York v. United States, ruled that "Congress may not 'commandeer' state regulatory processes by ordering states to enact or administer a federal regulatory program." ${ }^{126}$ Justice Sandra Day O'Connor, who authored the opinion, emphasized that " $[\mathrm{s}]$ tate officials cannot consent to the enlargement of the powers of Congress beyond those enumerated in the Constitution"'127 Sensing that states could be co-opted by an ambitious Congress or President at the expense of the freedoms recognized in the Bill of Rights and the equal protection guaranteed by the $14^{\text {th }}$ Amendment, ${ }^{128}$ Justice O'Connor declared that U.S. constitutional federalism is intended to ensure the supremacy of individual liberty over the rights of the states and the federal government.

The Constitution does not protect the sovereignty of States for the benefit of the States or state governments as abstract political entities, or even for the benefit of the public officials governing the States. To the contrary, the Constitution divides authority between federal and state governments for the protection of individuals. State sovereignty is not just an end in itself: 'Rather,

\footnotetext{
${ }^{124}$ See Alexandra B. Klass, State Standards for Nationwide Products Revisited: Federalism, Green Building Codes, and Appliance Efficiency Standards, 34 HARV. ENVTL. L. REV. 335, 341-342 (2010).

${ }^{125} I d$. at 342.

${ }^{126}$ New York v. United States, 505 U.S. at 145.

${ }^{127} I d$. at 144.

${ }^{128}$ See Rob Natelson, It's the People's Right!, TENTH AMENDMENT CTR. (May 22, 2009), http://tenthamendmentcenter.com/2009/05/22/its-the-peoples-right/.
} 
federalism secures to citizens the liberties that derive from the diffusion of sovereign power' (emphasis added). ${ }^{129}$

Just as the separation and independence of the coordinate branches of the Federal Government serve to prevent the accumulation of excessive power in any one branch, a bealtby balance of power between the States and the Federal Government will reduce the risk of tyranny and abuse from either front (emphasis added). ${ }^{130}$

Perhaps the current White House and its progressive acolytes in federal, state, and local government should keep this Supreme Court admonition in mind as they endeavor to enact into law post-modernist international SD initiatives premised on Europe's precautionary principle that reject empirical science, rule of law, neoliberal economics, and private property rights. ${ }^{131}$

${ }^{129}$ New York v. United States, 505 U.S. at 145 (quoting Coleman v. Thompson, 501 U.S. 722, 759 (1991) (Blackmun, J., dissenting)).

${ }^{130}$ Gregory v. Ashcroft, 501 U.S. 452, 458 (1991).

131 See, e.g., Invasion of the Property Snatchers, INST. FOR TRADE, STANDARDS AND SUSTAINABLE DEV. (Oct. 31 , 2006), http://nebula.wsimg.com/8088808a02bf53014f9d0d19e555f6e7?AccessKeyId=39A2DC689E4CA87C 906D\&disposition=0\&alloworigin=1; U.S. Property Rights Are Under International Assault: The ITSSD Identifies How U.S. Internationalists Are Assisting Attivist Groups and Foreign Governments to Weaken U.S. Private Property Rights Via Regulation and Compulsory Licensing, PRNEWSWIRE (Oct. 31, 2006), http://www.prnewswire.com/news-releases/us-property-rights-are-under-international-assault56639992.html; Lawrence A. Kogan, Inst. for Trade, Standards and Sustainable Dev., Address Presented at the 10th Annual Property Rights Foundation of America Conference: U.S. Private Property Rights Under International Assault, (Oct. 14, 2006), transcript available at http://prfamerica.org/speeches/10th/USPrivatePropertyRightsUnderIntlAssault.html. 